\title{
The Influencing Factors on Taxpayer Compliance: A Conceptual Approach
}

\author{
Khoirul Aswar, Ermawati, Tresia Risda Saragih \\ Universitas Pembangunan Nasional Veteran Jakarta, Indonesia \\ aswar_law@yahoo.com
}

\begin{abstract}
Starting from the assumption that the problem of taxpayer compliance is important issues throughout the world, both in developed countries and in developing countries because if the taxpayer does not comply, it will cause the desire to do so acts of avoidance, evasion and tax neglect. This research seeks to find out to what extent taxpayers registered with SAMSAT Bekasi City fulfill Motorized vehicle tax liability. Drawing from institutional theory, this study has six objectives: (i) to find out the application of understanding of regulations taxation of taxpayer compliance, (ii) to determine the application of sanctions tax on taxpayer compliance, (iii) to determine the application of the tax rate to taxpayer compliance, (iv) to determine the effect of the application of preferences risks to taxpayer compliance. Therefore, this research contributes to the development of science knowledge and is expected to apply the theory that has been obtained specifically regarding the influence of understanding of tax regulations, tax sanctions, risk preferences and the tax rate for taxpayer compliance.
\end{abstract}

Keywords: Understanding of tax regulations, Tax sanctions, Tax rates, Risk preferences, Taxpayer compliance.

\section{Introduction}

In general, tax is compulsory contributions paid by the people to a country which useful for the benefit of government and society because tax is state revenue that will be used for the construction of public facilities. Therefore, taxes are important for state income. National development is one of the ongoing government activities continuously. State revenue in 2018 amounted to Rp1,942.3 trillion or $102.5 \%$ with the tax ratio reaches $11.5 \%$ of the increased Gross Domestic Product (GDP) by $0.8 \%$ from 2017 (Kemen, 2019). Even so, the acceptance ratio tax in Indonesia is the lowest among the G-20 countries and countries emerging markets. To be equal to developing countries, Indonesia needs to have a tax ratio of $20 \%$ of GDP. To achieve this target the government seeks to reform taxation in various ways, one of which is building tax compliance and awareness. Level of compliance Indonesian people in paying taxes are still very low compared to other countries, as a comparison of the tax ratio in Malaysia of 16\%, the Philippines 14\%, Thailand 17\%, South Korea 25\%, South Africa 27\%, and Brazil 34\% (Detik Finance, 2018). In Bekasi city of Indonesia, data from the Tribun 2018 showed the local tax target and realization in Bekasi as in Table 1.

Table 1: Tax Target and Realization Motorized Vehicles

\begin{tabular}{lll}
\hline Tax Target & Realization & Percentage \\
\hline Rp. 928,833,000,000 & Rp. 326,292,255,850 & $35.13 \%$ \\
\hline
\end{tabular}

Based on the Table 1 it shows that tax target in Bekasi will reach Rp. 928,833,000,000, but the realization was $35.13 \%$ or Rp. 326,292,255,850, with a total of 1,459,933 units of motorized vehicles. In April 2018, 546,922 units of vehicles have not been paid annual taxes motorized vehicles or $37.46 \%$ (Tribun, 2018). The results of previous studies stated that tax sanctions have a significant relationship with taxpayer compliance. In January 2019, the number of motorized vehicles was at Bekasi as many as 1,613,317 units, while the number of motorized vehicles is as much 620,073 units are still in arrears on motor vehicle tax with the potential for mandatory receivables the tax is estimated to be more than IDR 186,000,000,000. According to research results in the field the reason Bekasi residents are in arrears in tax payments is because lack of awareness of paying taxes and his financial condition (Tempo, 2019). Based on the above, the researcher wants to conduct a research related to tax compliance. One reason for the low morale of a tax is a tax rate that is too high so it is burdensome for the mandatory tax. In the study of Atawodi and Ojeka (2012) high tax rates is a factor the most important thing that causes non-compliance with taxes. Tax rate motorized vehicles are regulated in Law No. 28 of 2009 article 6, namely for first motor vehicle ownership is at least 1\% (one percent) and the highest of $2 \%$ (two percent). There are a few studies related to the effect of tax rates on taxpayer compliance such as research conducted by Cahyani and Naniek (2019), Tawas, Poputra, and Lambey (2016), Helhel and 
Ahmed (2014), Atawodi and Ojeka (2012) shows that tax rates have a positive and significantly on taxpayer compliance.

In contrary, study conducted by Mas'ud, Aliyu, and Gambo (2014) which the results of the study tax rates have, a negative and significantly on taxpayer compliance, and research conducted by Mustofa, Kertahdi and Mirza (2016), Yusro and Kriswanto (2013) which stated that the tax rate is not affect the compliance of taxpayers. In addition, an understanding of tax regulations is also a factor which affects taxpayer compliance. If taxpayers understand more about taxation regulations, the more taxpayers will understand the sanctions that will be accepted if they neglect their tax obligations (Ananda, Kumadji, \& Husaini, 2015). There are several studies related to understanding regulations taxation of taxpayer compliance which is the result of the research understanding of tax regulations has a positive and significantly relationship with mandatory compliance taxes (Cahyani \& Naniek 2019, Mareti \& Dwimulyani 2019, Asrianti 2018, Utari \& Setiawan 2019, Ananda, et al., 2015, Adiasa 2013). The results of the study are inversely proportional to research by Syah and Krisidiyawati (2017), Andinata (2015), Mas'ud et al. (2014) in which the understanding of tax regulations has no relationship with taxpayer compliance.

Furthermore, another factor that is considered to affect tax compliance is tax sanctions. There are several studies related to the relationship between tax sanctions with taxpayer compliance conducted by Cahyani and Naniek (2019), Mareti and Dwimulyani (2019), Asrianti (2018), Syah and Krisdiyawati (2017), Setiawan and Meliana (2017), Tawas, et al. (2016), Helhel and Ahmed (2014), Ardyanto and Utaminingsih (2014) shows that tax sanctions have a positive and significantly on taxpayer compliance. The results of this study are inversely proportional to that of the study conducted by Rahmawati and Yulianto (2018), Andinata (2015), Pranata, Hamdi, and Herawati (2015) which states that tax sanctions do not have a relationship with tax taxpayer compliance. According to Alabede, et al. (2011) things that must be considered in taxpayers making tax payments is a risk that taxpayers must consider before making tax payments. Torgler (2003) conveys that decision a taxpayer can be influenced by his behavior towards the risks faced. Furthermore, the purpose of this study is to determine understanding of tax regulations, tax sanction tax rate and risk preference on the taxpayer compliance.

\section{Theoretical Perspective}

Prospect Theory: Prospect theory is a theory that explains how one takes decisions in uncertain conditions. Prospect theory was first developed by Daniel Kahneman and Amos Tversky in the early 1980s, where this theory is includes two scientific disciplines namely psychology and economics which is an analysis a person's behavior in making decisions between two choices. Related research uses prospect theory as a theoretical basis for examines taxpayer compliance with risk preferences as moderation, which is Mareti and Dwimulyani (2019), Irawati and Sari (2019), Tambun and Witriyanto (2016), Setiawan and Meliana (2017), Ardyanto and Utaminingsih (2014), Adiasa (2013), Aryobimo and Cahyonowati (2012), Alabede, et al. (2011), and Torgler (2003). The relationship of this research to prospect theory is to explain preferences risks can affect taxpayer compliance. The results of previous studies stated that tax sanctions have a significant relationship with taxpayer compliance. If a taxpayer has high risk, the taxpayer will not necessarily pay the obligation the tax because if the taxpayer has the risk seeking nature though taxpayers have a high risk then it will not affect taxpayers to keep paying taxes, whereas taxpayers who have the risk aversion if taxpayers have low risk, the taxpayers will avoid it tax liability.

Theory Planned of Behavior: Theory of planned behavior is a theory that emphasizes the rationality of human conduct is likewise in the conviction that the objective conduct is beneath control of individual consciousness. According to Ajezen (1991), individual behavior is influenced by behavioral intention towards that behavior. There are three Components in theory planned behavior, include: Behavioral beliefs, individual beliefs will result from a behavior and evaluation of these results (beliefs strength and outcome evaluation), such as taxpayer awareness. This theory explains that taxpayers will comply or not in their obligations in the field of taxation by considering the benefits and effects of his actions in paying taxes. In addition the taxpayer will consider the information obtained from outside. Thus, taxpayers will be influenced by certain factors in his actions are control of trust. Research that uses theory of planned behavior as a theoretical basis for examining taxpayer compliance, Widanaputra and Ratnadi (2019) using the independent variable awareness 
of taxpayers, obligations moral, and environment, Novianti and Dewi (2017) with independent variables which used is tax amnesty, and Nugraheni and Purwanto (2015) with variables independent awareness of taxpayers, tax knowledge and understanding, sanctions tax, the tax authority, attributable justice, the quality of tax services, procedural justice, and interactional justice.

Hypothesis and Thinking Framework: The development of hypotheses in this study is based on factors that are allegedly having an influence on the level of tax compliance, so that it can formulate as follows:

Effects of Understanding of Taxation Regulations on Taxpayer Compliance: An understanding of taxation is needed so that taxpayers understand; understand, to be able to apply what is contained in the regulations listed. In research Cahyani and Naniek (2019), Mareti and Dwimulyani (2019), Utari and Setiawan (2019), Asrianti (2018), Mustofa, dkk (2016), Ananda, et al. (2015), and Adiasa (2013) examine the influence of understanding of regulations taxation of taxpayer compliance. The results of previous studies stated that understanding of tax regulations has a significant effect on taxpayer compliance. The hypothesis can be formulating as follows:

H1: Understanding tax regulations has a significant on rates taxpayer compliance.

Effects of Tax Sanctions on Taxpayer Compliance: Tax sanctions must be given as a form of punishment for taxpayers who are breaking the rules will be a deterrent so as not to repeat it again so creating an increase in tax compliance. The various studies by Cahyani and Naniek's (2019), Mareti and Dwimulyani (2019), Asrianti (2018), Mustofa, et al. (2016), Syah and Krisdiyawati (2017), Setiawan and Meliana (2017), Tawas, et al. (2016), Helhel and Ahmde (2014), Ardyanto and Utaminingsih (2014) tested tax sanctions for taxpayer compliance. The results of previous studies stated that tax sanctions have a significant relationship with taxpayer compliance. Based on description above, then the hypothesis can be formulated as follows:

H2: A Tax sanction has a significant effect on taxpayer compliance.

Effect of Tax Rates on Taxpayer Compliance: The tax rate is the amount of value that must be paid by taxpayers to country through the fiscus. In the study of Atawodi and Ojeka (2012) stated that exorbitant tax rate cause taxpayer non-compliance. In the research of Cahyani and Naniek (2019), Tawas, et al. (2016), Helhel and Ahmed (2014), and Atawodi and Ojeka (2012) examine the tax rate on taxpayer compliance. The results of previous studies stated that the tax rate has significant effect taxpayer compliance. It can be formulated hypothesis as follows:

H3: Tax rates have a significant effect on taxpayer compliance.

Effect of Risk Preference on Taxpayer Compliance: According to Torgler (2003) Risk preferences can affect a person's decision taxpayers against the risks faced. The risk of being the one considered taxpayers in paying taxes (Alabede, et al., 2011). When risk preferences have a strong relationship with taxpayer compliance, then the level of taxpayer compliance will be low. In the research of Dwi, et al. (2018) as well Aryobimo and Cahyonowati (2012) risk preferences has a positive effect on taxpayer compliance. On the other hand, in the research of Irawati and Sari (2019), Setiawan and Meliana (2017), Adiasa (2013) risk preference has no effect on compliance taxpayer. Based on the description, the hypothesis can be formulated as following:

H4: Risk preference has a significant effect on taxpayer compliance. 


\section{Figure 1: Research Framework}

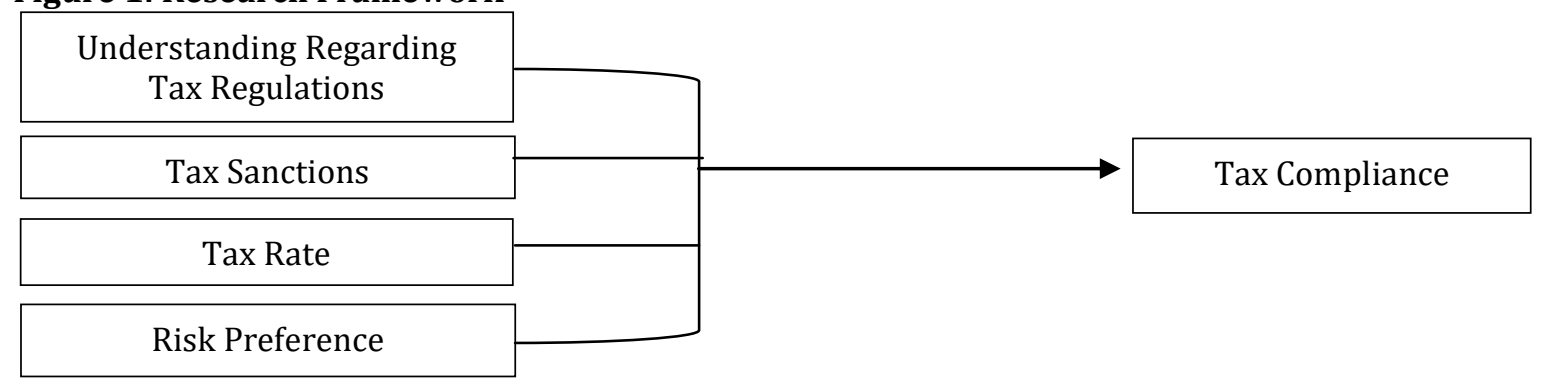

\section{Proposed Method}

The method in this study is a questionnaire survey distributed to taxpayers registered at SAMSAT Bekasi City. The population in this study is entire taxpayers registered at SAMSAT Bekasi with consisting 1.613.317. Samples obtained in this study were 99 respondents. This study intends to employ accidental sampling. It is further suggested that future studies should target a sample of Bekasi city. This study tries to get the opinion of taxpayers in Bekasi City SAMSAT who is paying motor vehicle taxes. It is further suggested that future empirical studies should target a wider sample and be able to expand the object of research throughout the SAMSAT in the Bekasi area so that this research can be used universally.

\section{Conclusion}

The conceptual paper in this study to investigate about factors which affects taxpayer compliance, especially in SAMSAT, Bekasi City this matter is important because taxes are useful state income to finance state expenditure, build public facilities, as well as for sustainability development. This research begins with the problem of taxpayer compliance in Indonesia which is still low and requires improvements to taxpayer compliance. Problems with taxpayer compliance also occur with motor vehicle tax at SAMSAT Bekasi. This study aims to examine and determine the factors that influence taxpayer compliance with risk preference as a moderating variable. Factors that affect taxpayer compliance measured by 26 statements the findings in this study are expected to contribute to improve taxpayer compliance and to explore impacts various factors such as understanding taxation regulations, tax sanctions, tax rate and risk preferences. It is hoped that the objectives of this research will be achieved to contribute to the taxpayer and SAMSAT of Bekasi City.

In order to be able to anticipate other factors that will later influence tax compliance. SAMSAT Bekasi are expected to be more active in providing information to the whole community through tax socialization to improve tax knowledge and understanding both directly and through the mass media regarding the importance of paying taxes on time, increasing supervision with zebra operations, and improving services to minimize the existence of brokers. Then, for further research it is expected to be able to add other variables such as awareness of taxpayers, taxation socialization, service quality of fiskus and use the taxation understanding variable as a moderating variable and expand the object of research not only to one SAMSAT but to all SAMSAT in the Bekasi area so that research can be used universally. Overall, the results of this conceptual paper must also produce insights important for SAMSAT Bekasi and can be a reference for research next.

\section{References}

Andinata, M. C. (2015). Analisis faktor-faktor yang mempengaruhi Kepatuhan wajib pajak orang pribadi dalam membayar pajak (Studi kasus pada kantor pelayanan pajak pratama rungkut di Surabaya), Calyptra: Jurnal Ilmiah Mahasiswa Universitas Surabaya, 4(2), 1-5.

Adiasa, N. (2013). Pengaruh pemahaman peraturan pajak terhadap kepatuhan wajib pajak dengan moderating preferensi risiko, Accounting Analysis Journal, 2(3), 345-352.

Ajezen, I. (1991). The theory of planned behavior, organizational behavior and human decision processes, $50(2), 179-211$. 
Alabede, J. O., Ariffin, Z. Z. \& Idris, K. M. (2011). Individual taxpayers' attitude and compliance behaviour in Nigeria: the moderating role of financial condition and risk preference, Journal of Accounting and Taxation, 3(5), 91-104.

Ananda, P. R. D., Kumadji, S. \& Husaini, A. (2015). Pengaruh sosialisasi perpajakan, tarif pajak, dan pemahaman perpajakan terhadap kepatuhan wajib pajak (Studi pada UMKM yang terdaftar sebagai wajib pajak di kantor pelayanan pajak pratama Batu), Jurnal Perpajakan, 6(2), 1-9.

Ardyanto, A. A. \& Utaminingsoh, N. S. (2014). Pengaruh sanksi pajak dan pelayanan aparat pajak terhadap kepatuhan wajib pajak dengan preferensi risiko sebagai variable moderasi, Accounting Analysis Journal, 3(2), 220-229.

Aryobimo, P. T. \& Cahyonowati, N. (2012). Pengaruh persepsi wajib tentang kualitas pelayanan fiskus terhadap kepatuhan wajib pajak dengan kondisi keuangan dan preferensi risiko sebagai variable moderating, Diponegoro Journal of Accounting, 3(2), 1-1.

Asrianti. (2018). Pengaruh pemahaman dan sanksi perpajakan terhadap kepatuhan wajib pajak dengan preferensi risiko seebagai variable moderasi (Studi pada KPP Pratama Makassar Selatan). Publikasi Program Sarjana Akuntansi, Universitas Islam Negeri Alauddin Makassar.

Atawodi, O. W. \& Ojeka, S. A. (2012). Factors that affect tax compliance among small and medium enterprises (SMEs) in North Central Nigeria, International Journal of Business and Management, 7(12), 87-96.

Cahyani, L. P. G. \& Noviari, N. (2019). Pengaruh tarif pajak, pemahaman perpajakan, dan sanksi perpajakan terhadap kepatuhan wajib pajak UMKM, E-Jurnal Akuntansi Universitas Udayana, 26(3), 1885-1991.

Detik Finance. (2018). Tingkat kepatuhan pajak masyarakat masih rendah.

Dwi, Y., Paramita, P. D. \& Prananditya, A. (2018). Pegaruh pemahaman peraturan perpajakan dan kesadaran wajib pajak terhadap kepatuhan wajib pajak dengan preferensi risiko sebagai variable moderating. Journal of Accounting, 1-10.

Helhel, Y. \& Ahmed, Y. (2014). Factors affecting tax attitudes and tax compliance: A survey study in Yemen. European Journal of Business and Management, 6(22), 48-58.

Irawati, W. \& Sari, A. K. (2019). Pengaruh persepsi wajib pajak dan preferensi risiko terhadap kepatuhan wajib pajak. Jurnal Akuntansi Barelang, 3(2), 104-114.

Kemen. (2019). Ini capaian apbn 2018.

Mareti, E. D. \& Dwimulyani, S. (2019). Pengaruh pemahaman peraturan perpajakan, kualitas pelayanan fiskus, sanksi perpajakan, dan tax amnesty terhadap kepatuhan wajib pajak dengan preferensi risiko sebagai variable moderasi, Prosiding Seminar Nasional Pakar ke, 2, 1-16.

Mas'ud, A., Aliyu, A. A. \& Gambo, E. J. (2014). Tax rate and tax compliance in Africa. European Journal of Accounting Auditing and Finance Research, 2(3), 22-30.

Mustofa, F. A. \& Kertahdi, R. M. M. (2016). Pengaruh pemahaman peraturan perpajakan, tarif pajak, dan asas keadilan terhadap kepatuhan wajib pajak (Studi pada wajib pajak usaha mikro kecil dan menengah yang berada di wilayah kerja kantor pelayanan pajak pratama Batu setelah diberlakukannya Peraturan Pemerintah Nomor 46 Tahun 2013), Jurnal Perpajakan (JEJAK), 8(1), 1-7.

Novianti, A. F. \& Dewi, N. H. U. (2017). An investigation of the theory of planned behavior and the Role of tax amnesty in tax compliance, The Indonesian Accounting Review, 7(1), 79-94.

Nugraheni, A. D. \& Purwanto, A. (2015). Faktor-faktor yang mempengaruhi kepatuhan wajib pajak orang pribadi (Studi empiris pada wajib pajak di Kota Magelang), Diponegoro Journal of Accounting, 4(3), 114.

Pranata, T. A., Hamdi, M. \& Herawati. (2015). Pengaruh kesadaran wajib pajak, sanksi denda pajak, dan kualitas pelayanan pajak terhadap kepatuhan wajib pajak dalam membayar pajak kendaraan bermotor di Kota Bukittinggi, Jurnal Universitas Bung Hatta, 2-15.

Rahmawati, R. \& Yulianto, A. (2018). Analysis of the factors affecting individual taxpayer compliance, Accounting Analysis Journal, 7(1), 17-24.

Setiawan, A. B. \& Meliana, S. (2017). Analisis kepatuhan wajib pajak hotel berdasarkan pemeriksaan pajak, sanksi perpajakan, kondisi keuangan, dan preferensi risiko pada hotel-hotel yang terdaftar di BAPPENDA Kabupaten Bogor. Jurnal Akunida, 3(2), 13-26.

Syah, A. L. N. \& Krisdiyawati. (2017). Analisis faktor-faktor yang memepengaruhi kepatuhan wajib pajak dalam membayar pajak kendaraan bermotor (Studi empiris pada kantor UPPD/ SAMSAT Brebes), Jurnal AKSI (Akuntansi dan Sistem Informasi), 2(1), 65-77.

Tambun, S. \& Witriyanto, E. (2016). Pengaruh kesadaran wajib pajak dan penerapan e-system terhadap tingkat kepatuhan wajib pajak dengan preferensi resiko sebagai variable moderating (Studi empiris 
kepada wajib pajak di komplek perumahan sunter agung Jakarta Utara), Media Akuntansi Perpajakan, 1(2), 86-94.

Tawas, V. B. J., Poputra, A. T. \& Lambey, R. (2016). Pengaruh sosialisasi perpajakan, tarif pajak, dan sanksi perpajakan terhadap kepatuhan pelaporan SPT tahunan wajib pajak orang pribadi (Studi kasus pada KPP pratama Bitung), Jurnal EMBA, 4(4), 912- 921.

Tempo. (2019). Tunggakan kendaraan bermotor di Kota Bekasi.

Torgler, B. (2003). Tax morale: Theory and analysis of tax compliance. Unpublished doctoral dissertation, University of Zurich, Switzerland.

Tribun. (2018). Target pendapatan pajak kendaraan bermotor Kota Bekasi.

Utari, P. D. A. \& Setiawan, P. E. (2019). Pengaruh pemahaman peraturan perpajakan terhadap kepatuhan WPOP dengan preferensi risiko sebagai variable pemoderasi, E-Jurnal Akuntansi, 28(1), 109-131.

Widanaputra, A. A. G. P., Ratnadi, N. M. D. \& Putra, I. N. W. A. (2019). Internal and external factors affecting taxpayer compliance of tax amnesty participants, International Journal of Economics, Commerce and Management, 4, 314- 331.

Yusro, H. W. \& Kiswanto. (2013). Pengaruh tarif pajak, mekanisme pembayaran pajak dan kesadaran membayar pajak terhadap kepatuhan wajib pajak UMKM di Kabupaten Jepara, Accounting Analysis Journal, 3(4), 429-436. 